\title{
PENGARUH MODEL KOOPERATIF TIPE NUMBERED HEAD TOGETHER \\ (NHT) TERHADAP HASIL BELAJAR PPKn PADA SISWA KELAS III SEKOLAH DASAR
}

\author{
Rini1, Rauldatul Husni ${ }^{2}$, Gingga Prananda ${ }^{3}$ \\ ${ }^{1}$ Mahasiswa universitas dharmas indonesia \\ ${ }^{2}$ dosen universitas dharmas indonesia \\ ${ }^{3}$ dosen universitas dharmas indonesia
}

Email: rinimarisa3@gmail.com

\begin{abstract}
This research is motivated by the findings of researchres, namely the low learning outcomes of students in civics subjekct in third grade students of SDN 30/II Tanjung. The learning process only uses the lecture method. Therefore, many student learning outcomes are belw the maximum completeness criteria. For this reason, researchers conducted a study using the Numbered Head Together (NHT). Model the purpose of this study was to determine the effect of the Numbered Head Together (NHT) cooperative model on civics learning outcomes in third grade elementary school students. This type of research is a pre experimental design. This research design is a one group pretest-postest design. The research was conducted at SDN 30/II Tanjung. When this research was carrid out in the second semester of 2020/2021, it was adjusted to the thematic learning schedule for class III PPKn content at SDN 30/II Tanjung. The sample in this study amounted to 22 students. Based on the results of the paired samples $t$ test, a significance of $0.000<0.05$ was obtained. It can be concluded the there is an effect of Numbered Head Together (NHT) cooperative model on civics learning outcomes in third grade elementary school students. Based on research, that the model Numbered Head Together (NHT). Give a good influeance on the learning outcomes of civics. Numbered Head Together (NHT) can be used by teachers to relate subject matter to the real world of students, become active studenst and the Numbered Head Together (NHT) model can increase studenst learning outcomes. Keywords, PPKn content, model Numbered Head Together (NHT), learning outcomes.
\end{abstract}


Abstrak: Penelitian ini dilatar belakangi oleh temuan peneliti yaitu rendahnya hasil belajar siswa pada mata pelajaran PPKn pada siswa kelas III SDN 30/II Tanjung. Proses pembelajaran hanya menggunakan metode ceramah. Oleh karena itu hasil belajar siswa banyak yang di bawah KKM. Untuk itu, peneliti melakukan suatu penelitian menggunakan model Numbered Head Together (NHT). Tujuan penelitian ini untuk mengetahui pengaruh model Kooperatif Tipe Numbered Head Together (NHT) Terhadap Hasil Belajar PPKn Pada Siswa Kelas III Sekolah Dasar. Jenis penelitian ini adalah pre experimental design. Desain penelitian ini adalah one group pretest-posttest design. Penelitian dilakukan di SDN 30/ II Tanjung. Waktu dilaksanakannya penelitian ini pada semester II Tahun Pelajaran 2020/2021, disesuaikan pada jadwal pembelajaran tematik muatan PPKn kelas SDN 30/ II Tanjung. Sampel pada penelitian ini berjumlah 22 siswa. Berdasarkan hasil uji paired samples $t$ test diperoleh signifikasi $0,000<0,05$. Dapat disimpulkan bahwa terdapat pengaruh model Numbered Head Together (NHT) terhadap hasil belajar PPKn pada siswa kelas III sekolah dasar. Berdasarkan penelitian, bahwa model Numbered Head Together (NHT). memberikan pengaruh yang baik terhadap hasil belajar PPKn. Numbered Head Together (NHT) dapat digunakan guru untuk mengaitkan materi pelajaran dengan dunia nyata siswa, menjadikan siswa aktif serta model Numbered Head Together (NHT) dapat meningkatkan hasil belajar siswa.

Kata Kunci: muatan PPKn, model Numbered Head Together (NHT), hasil belajar. PENDAHULUAN

Pendidikan mampu menumbuhkan dan mengembangkan potensi yang ada dalam diri siswa sehingga dapat menyesuaikan diri sebaik mungkin terhadap lingkungan. Sebagaimana yang diterapkan dalam Undang-Undang Republik Indonesia Nomor 12 tahun 2012 tentang Pendidikan Tinggi BAB I Pasal 1 yang menyatakan bahwa, Pendidikan adalah usaha sadar dan terencana untuk mewujudkan suasana belajar dan proses pembelajaran agar siswa secara aktif mengembangkan potensi dirinya untuk memiliki kekuatan spiritual keagamaan, pengendalian diri, kepribadian, kecerdasan, akhlak mulia, serta keterampilan yang diperlukan dirinya, masyarakat, bangsa dan negara.

Pendidikan merupakan usaha mendewasakan manusia secara sadar dan sengaja melalui upaya pengajaran, tanpa adanya pendidikan manusia tidak akan mampu menghadapi perubahan yang terjadi akibat kemajuan teknologi, jadi pendidikan itu sangat penting bagi 
kehidupan manusia, baik secara diri sendiri, masyarakat, bangsa dan negara. Dalam Jenjang Lembaga Pendidikan Nasional, SD, merupakan jenjang pendidikan yang yang paling rendah setelah TK/PAUD, fungsi penting pendidikan sekolah dasar yaitu mengembangkan kemampuan dasar sebagai bekal bagi peserta didik mendewasakan diri dalam kehidupan bermasyarakat. Peserta didik merupakan anggota masyarakat yang berusaha mengembangkan potensi diri melalui jenjang, jalur dan jenis pendidikan tertentu untuk terus mengikuti kemajuan teknologi yang tidak dapat dihindari.

Berdasarkan observasi yang dilakukan peneliti yang pernah melakukan Pengenalan Lapangan Persekolahan (PLP) di kelas III SDN 30/II Tanjung yang dimulai pada hari Selasa 04 Agustus 2020 sampai hari Rabu 23 Desember 2020, bahwa saat pembelajaran PPKn berlangsung, siswa hanya mendengarkan penyampaian materi dari guru secara verbal tanpa mengaitkan dengan lingkungan nyata dan tidak ada kesempatan untuk mengembangkan kemampuan berpikir sehingga siswa menjadi kurang aktif. Hanya sebagian saja siswa yang menulis materi yang diberikan guru tanpa menemukan dan membangun pengetahuannya sendiri melalui pengamatan serta sebagian siswa bercerita dengan teman sebangkunya. Masalah yang dihadapi sekarang ialah rendahnya hasil belajar siswa pada pembelajaran PPKn. Sehingga masalah ini berdampak pada banyaknya siswa yang belum mencapai KKM yaitu 70 . Faktor penyebab rendahnya hasil belajar siswa hanya bergantung pada kemampuan

siswa yang lain, dan kurangnya pemahaman tentang materi yang disampaikan oleh guru sehingga siswa yang lain tidak siap untuk menjawab pertanyaan.

Faktor penyebab rendahnya hasil belajar PPKn siswa kelas III SD disebabkan oleh kurang tepatnya model dan media yang digunakan guru. Adapun model yang telah digunakan guru dalam pembelajaran PPKn adalah metode ceramah. Sedangkan media yang digunakan guru hanya buku paket saja, guru tidak menggunakan model pembelajaran yang lebih bervariasi. Sehingga guru kelas mengalami permasalahan pada meningkatkan hasil belajar siswa dalam menulis, oleh karena itu diperlukan model pembelajaran yang tepat dan bersifat aktif sehingga siswa tertarik dalam mengikuti pembelajaran. Untuk mengatasi rendahnya hasil belajar PPKn siswa diperlukan model yang menarik dan tepat agar siswa mudah memahami materi. Oleh sebab itu, peneliti akan menerapkan model pembelajaran kooperatif tipe Numbered Head Together (NHT). 
Model pembelajaran kooperatif adalah mampu mengajak siswa untuk berkomunikasi dan berinteraksi sosial dengan siswa dengan siswa lain (Utami, 2018). Model pembelajaran kooperatif adalah suatu pembelajaran dengan mengelompokan siswa ke dalam kelompok kecil dengan anggota kelompok antara 4 sampai 6 orang, dan dengan kemampuan yang berbeda-beda.

Model pembelajaran Numbered Head Together (NHT) merupakan suatu model pembelajaran berkelompok yang dimana setiap anggota kelompoknya akan diberi tanggung jawab atas tugas yang diterimanya, setiap anggota kelompok akan diberikan nomor yang sesuai dengan jumlah pada anggota kelompok yang di bentuk (Diah et al, 2017). Numbered Head Together (NHT) juga mampu meningkatkan semangat kerja sama siswa dan dapat digunakan untuk semua mata pelajaran dan tingkatan kelas.

Model pembelajaran koopetatif tipe Numbered Head Togrther (NHT) digunakan dalam pembelajaran memiliki langkah-langkah yang perlu dipahami dengan baik. Shoimin (2014) adalah sebagai berikut, 1) Siswa dibagi dalam kelompok. Setiap siswa dalam setiap kelompok mendapat nomor, 2) Guru memberikan tugas dan masing-masing kelompok mengerjakannya. 3) Kelompok mendiskusikan jawaban yang benar dan memastikan tiap anggota kelompok dapat mengerjakannya atau mengetahui jawabannya dengan baik, 4) Guru memanggil salah satu nomor siswa dan nomor yang dipanggil keluar dari kelompoknya melaporkan atau menjelaskan hasil kerja sama mereka, 5) Tanggapan dengan teman yang lain, kemudian guru menunjuk nomor yang lain, 6) Kesimpulan.

Selain menggunakan langkah-langkah model NHT juga memiliki beberapa kelebihan dan kelemahan Febriany (2013) mengemukan kelebihan dan kelemahan model NHT, antara lain: Kelebihan, a) Setiap siswa menjadi siap semua, b) Dapat melakukan diskusi dengan sungguh-sunggu, c) Siswa yang pandai dapat mengajari siswa yang kurang pandai. Kelemahan, a) Kemungkinan nomor yang dipanggil, dipanggil lagi oleh guru. b) Tidak semua anggota kelompok dipanggil oleh guru.

Belajar merupakan proses yang berhubungan antara guru dan siswa. Peristiwa pembelajaran terjadi apabila siswa secara aktif berinteraksi dengan lingkungan belajar yang diatur guru. proses perubahan di dalam keperibadian manusia dan perubahan tersebut ditampakan dalam bentuk peningkatan kualitas dan kuantitas tingkah laku seperti peningkatan kecakapan, pengetahuan, sikap, kebiasaan, pemahaman, keterampilan, daya pikir dan kemampuan-kemampuan yang lain (Prananda, 2019). 
Hasil belajar adalah hasil yang dicapai oleh siswa dalam bentuk perubahan perilaku yang cenderung menetap dari ranah kognitif, afektif, dan psikomotorik dari proses belajar yang telah dilakukan Pindo Hutauruk, (2018). Hasil belajar merupakan tolak ukur utama untuk mengetahui keberhasilan belajar siswa baik perubahan tingkah laku maupun pembelajaran sebagai akibat dari belajar. Menurut Prananda, (2020) Hasil belajar adalah bagian terpenting dari pembelajaran, karena itu perlu adanya pemaham tentang kemampuan siswa, dan memahami tingkat pengalam belajar siswa.

PPKn adalah salah satu mata pelajaran yang diajarkan pada tingkat SD/MI yang berisi tentang konsep, nilai, moral dan norma yang terkandung dalam pancasila dan UUD 1945. Pendidikan pancasila dan kewarganegaraan (PPKn) merupakan mata pelajaran yang terdiri sendiri sebagai suatu disiplin ilmu yang memfokuskan siswa untuk memahami dan melaksanakan hak-hak dan kewajiban serta melestarikan nilai-nilai luhur dan moral bangsa sehingga siswa menjadi warga negara yang cerdas, terampil dan bertanggung jawab dalam berbagai kehidupan baik dalam bermasyarakat, berbangsa, dan bernegara Kurniawan, (2017). Pembelajaran PPKn sebenarnya mempunyai peran yang sangat penting. Mata pelajaran PPKn diharapkan akan mampu membentuk siswa yang ideal memiliki mental yang kuat, sehingga dapat mengatasi permasalahan yang akan dihadapinya.

\section{METODE}

Jenis penelitian yang dilakukan oleh peneliti adalah pre experimental design. Menurut Sugiyono, (2019) bahwa "pre experimental design merupakan dasar dari penelitian eksperimen". Dikatakan dasar dari penelitian eksperimen karena mengikuti langkah-langkah dasar penelitian eksperimen. Desain pada penelitian ini merupakan bentuk penelitian one group pretest-posttest design. Pada desain penelitian ini terlebih dahulu siswa diberikan soal pretest, selanjutnya siswa diberi treatment (perlakuan) menggunakan model Kooperatif Tipe Numbered Head Together (NHT) kemudian setelah diberi treatment (perlakuan) siswa diberikan soal posttest. Berikut akan digambarkan pola desainnya. Prosedur pengumpulan data yaitu, Tes dapat diartikan sebagai serangkaian pertanyaan, Selain itu Sugiyono; ( 2019) menyatakan bahwa "tes merupakan sekumpulan pertanyaan yang digunakan untuk mengumpulkan data mengenai kemampuan kognitif siswa sebelum atau setelah proses pembelajaran berlangsung". 
Populasi merupakan suatu wilayah generalisasi yang terdiri atas: obyek/subyek yang mempunyai kualitas dan karakteristik tertentu yang ditetapkan oleh peneliti untuk mempelajari dan kemudian ditarik kesimpulannya Sugiyono, (2019). Keseluruhan objek penelitian merupakan keseluruhan objek peneliti, populasi dalam penelitian ini adalah seluruh siswa kelas III SD N 30/II Tanjung, terdiri dari satu kelas dengan jumlah siswa 22 orang. Sugiyono juga menjelaskan Sampel merupakan bagian dari jumlah dan karakteristik yang dimiliki oleh populasi tersebut. Teknik sampling jenuh merupakan teknik penentuan sampel bila semua anggota populasi digunakan sebagai sampel. Hal ini sering dilakukan bila jumlah populasi relatif kecil, kurang dari 30 orang, atau penelitian yang ingin membuat generalisasi dengan kesalahan yang sangat kecil. Istilah lain sampel jenuh adalah sensus, dimana semua anggota populasi dijadikan sampel.

\section{HASIL DAN PEMBAHASAN}

Tebel 4. 1 Data Hasil Pretest-Postes Siswa

\begin{tabular}{|c|c|c|}
\hline Deskripsi Data & Pretest & Posttest \\
\hline $\mathrm{N}$ & 22 & 22 \\
\hline$\sum x$ & 1105 & 1490 \\
\hline $\bar{x}$ & 52,61 & 70,95 \\
\hline Xmaks & 80 & 90 \\
\hline Xmin & 20 & 50 \\
\hline
\end{tabular}

Berdasarkan analisis siswa jumlah data pretest 1105 dan jumlah data posttest 1490 dan nilai rata-rata pretest 52,61 dan nilai posttest 70,95 nilai tertinggi pretest 80 dan nilai terendah pretest 20 nilai tertinggi posttest 90 dan nilai terendah posttest 50 . Berdasarkan nilai rata-rata tersebut terlihat bahwa nilai rata-rata posttest lebih tinggi daripada nilai ratarata pretest. Untuk dapat melihat secara jelas perbandingan nilai pretest dan posttest siswa maka peneliti menyajikan dalam bentuk diagram. Berikut diagram perbandingan nilai ratarata pretest dan posttest siswa kelas III SDN 30/II Tanjung. 


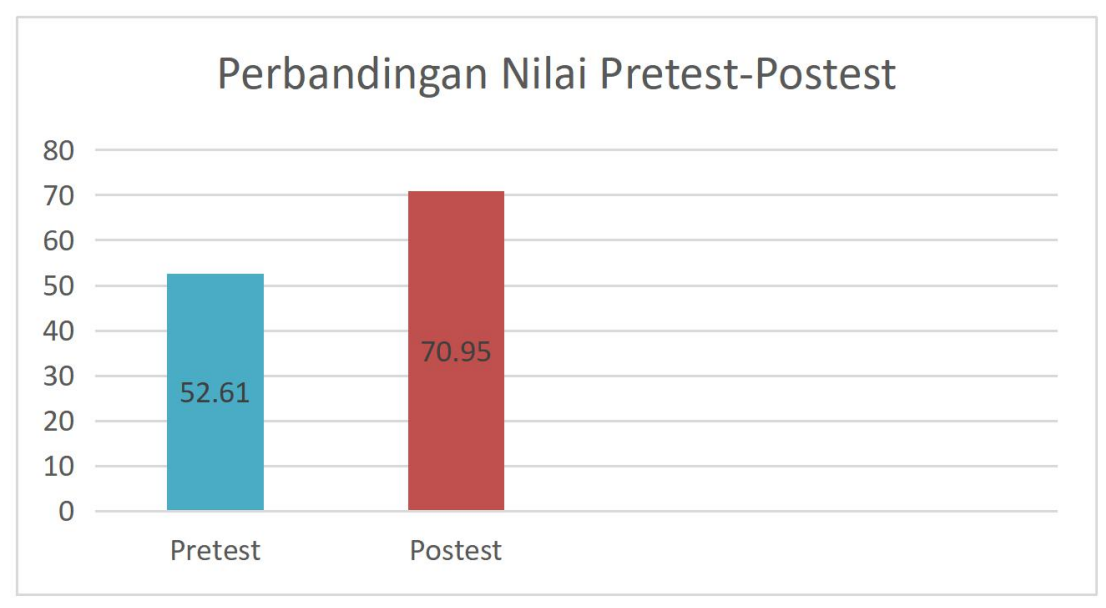

Gambar 4. 1 perbandingan Pretes dan Postest Siswa Kelas III

Gambar 4.1 menyajikan perbandingan nilai rata-rata Pretest dan Posttest siswa kelas III SDN 30/II Tanjung. Nilai rata-rata pretest adalah 52,61 sedangkan nilai rata-rata posttest adalah 70,95. Maka selisih antara nilai rata-rata Pretest dan Posttest yaitu sebesar 18,34. Dari selisih tersebut dapat dilihat bahwa perbandingan nilai meningkat dari nilai rata-rata pretest ke nilai rata-rata posttest. Artinya, nilai siswa meningkat setelah diberi treatment (perlakuan) menggunakan model Numbered Head Together (NHT). Selanjutnya untuk Uji persyaratan analisis yang digunakan adalah uji normalita, adapun kriteria pengujian yang digunakan adalah nilai $p$-value (Sig) lebih besar atau sama dengan $\alpha=0,05$ (Sig. $\geq 0,05$ ), maka $\mathrm{H}_{0}$ diterima. Uji normalitas yang digunakan dalam penelitian ini adalah Uji Shapiro-wilk, dengan menggunakan SPSS 22. Terlihat pada tabel 4.2 berikut:

Tabel 4. 2 Hasil Uji Normalitas Pretest-Postest

\begin{tabular}{|c|c|c|c|}
\hline Shapiro-wilk & Statistic & Sig & Kesimpulan \\
\hline Pretest & 0,934 & 0,151 & $\mathrm{H}_{0}$ diterima \\
\hline Posttest & 0,946 & 0,262 & $\mathrm{H}_{0}$ diterima \\
\hline
\end{tabular}

Sumber SPSS 22

Untuk mengetahui data tersebut berdistribusi normal atau tidak, maka dapat dilihat dari uji normalitas yang diperoleh. Jika nilai signifikansi 0,151>0,05 maka data dikatakan normal dan sebaliknya. Berdasarkan hasil uji normalitas pada tabel 4.2 dari Shapiro-wilk diperoleh data Pretest adalah 0,151 dan data posttest adalah 0,262 dengan $\alpha=0,05$ maka uji normalitas dari data hasil pretest adalah signifikasi $0,151>0,05$ dan hasil posttest adalah signifikasi $0,262>0,05$. Selanjutnya Pengajuan hipotesis dilakukan untuk mengetahui apakah hipotesis yang diajukan ditolak atau diterima. Setelah data pretest dan posttest hasil belajar siswa 
berdistribusi normal, maka dilakukan uji hipotesis. Peneliti menggunakan uji paired samples $t$ test Bertujuan untuk mengetahui apakah ada pengaruh atau tidak terhadap model pembelajaran yang digunakan dalam proses belajar mengajar pada siswa kelas III SDN 30/II Tanjung.

Tabel 43 uji hipotesis

\begin{tabular}{|l|c|c|}
\hline & $\mathrm{T}$ & Sig \\
\hline $\begin{array}{l}\text { Uji paired samples } \\
\text { test }\end{array}$ & 22,504 & 0,000 \\
\hline
\end{tabular}

Sumber: SPSS 22

Berdasarkan tabel 4.3 taraf signifikasi uji paired samples $t$ test adalah $0,000<0,05$ artinya $\mathrm{H}_{0}$ ditolak dan $\mathrm{H}_{\mathrm{a}}$ diterima hal ini berarti terdapat, untuk mengetahui ada atau tidaknya pengaruh model pembelajaran Numbered Head Together (NHT) dalam pembelajaran PPKn terhadap hasil belajar siswa kelas III SDN 30/II Tanjung. Maka dapat dilihat dari hasil hipotesis yang diperoleh. Berdasarkan hasil uji hipotesis pada tabel diatas dari uji Paired Sample Tes diperoleh hasil signifikasi sebesar 0,000. Karena nilai signifikasi $0,000<0,05$ maka hasil uji Paired Sample Tes dapat disimpilkan bahwa $\mathrm{H}_{0}$ ditolak dan $\mathrm{H}_{\mathrm{a}}$

diterima atau penggunaan model Numbered Head Together (NHT) berpengaruh terhadap hasil belajar siswa kelas III SDN 30/II Tanjung.

\section{PEMBAHASAN}

Berdasarkan soal pilihan ganda siswa kelas III SDN 30/II Tanjung yang berjumlah 22 siswa. Berdasarkan banyaknya siswa yang kurang aktif dan kurang konsentrasi dalam belajar maka dilakukan penelitian menggunakan model Numbered Head Together (NHT). Diharapkan model Numbered Head Together (NHT) dapat menjadikan siswa mampu meningkatkan hasil belajar dan mampu meningkatkan konsentrasi belajar siswa sehingga dapat berpengaruh baik terhadap hasil belajar siswa.

Langkah pertama penelitian yaitu peneliti memberikan soal pretest. Selanjutnya, peneliti melakukan treatment (perlakuan) pertama menggunakan model, Numbered Head Together (NHT) treatment (perlakuan) ini dilakukan sebanyak empat kali pertemuan. Terakhir, peneliti memberikan soal posttest kepada siswa. Adapun langkah-langkah penelitian ini sebagai berikut. 
Sebelum diberi treatmen (perlakuan), siswa diberi soal pretest sehingga hasil treatment (perlakuan) dapat diketahui lebih akurat, karena dapat membandingkan dengan keadaan sebelum dan setelah diberi treatment (perlakuan). Soal pretest khusus pada muatan PPKn menerima simbol sila-sila pancasila dalam lambang negara garuda pancasila, menerima sikap sesuai dengan sila-sila pancasila, memahami arti gambar pada lambang negara garuda pancasila, menceritakan arti gambar pada lambang negara.. Tes ini sebagai langkah awal pada proses penelitian eksperimen ini. Nilai pretest adalah nilai sebelum siswa diberikan treatment (perlakuan) menggunakan model Numbered Head Together (NHT). Nilai pretest siswa kelas III SDN 30/II Tanjung.

Selanjutnya, siswa diberi treatmen (perlakuan) menggunakan model Numbered Head Together (NHT) Treatmen (perlakuan) diberikan sebanyak empat kali pertemuan pada muatan PPKn materi memahami arti gambar pada lambang negara garuda pancasila. Peneliti telah mempersiapkan Rencana Pelaksanaan Pembelajaran (RPP) dan soal pilihan ganda guru pada setiap pertemuan guna untuk mengamati proses pembelajaran yang dilaksanakan oleh peneliti. Rencana Pelaksanaan Pembelajaran (RPP) yang digunakan oleh peneliti telah disesuaikan dengan model Numbered Head Together (NHT). Siswa mengalami proses pembelajaran dengan terlibat secara aktif. Guru mengajak siswa melakukan pengamatan atau memahami arti gambar pada lambang negara garuda pancasila dan menceritakan arti gambar pada lambang negara. Pada saat pengamatan di lingkungan sekolah terlihat bahwa siswa mampu dan cepat memahami arti gambar pada lambang negara garuda pancasila, sebab siswa dapat melihat langsung secara nyata contoh gambar pada lambang negara garuda pancasila yang ada di lingkungan sekolah tersebut.

Usai dilakukan penelitian di kelas III SDN 30/II Tanjung diperoleh data pretest dan posttest. Data pretest dapat dilihat pada tabel 4.1 dengan nilai rata-rata yang diperoleh 52,61 dan data posttest dapat dilihat pada tabel 4.1 dengan nilai rata-rata yang diperoleh sebesar 70,95. Selanjutnya, data pretest dan posttest yang diperoleh diuji normalitasnya. Hasil uji normalitas data pretest dan posttest memperoleh signifikansi $0,151>0,05$ dan $0,262>0,05$ artinya, data pretest dan posttest berdistribusi normal.

Setelah data berdistribusi normal, selanjutnya dilakukan uji hipotesis dengan menggunakan uji paired samples $t$ test. Hasil dari uji paired samples $t$ test yaitu dengan taraf signifikasi $\alpha=0,05$. Berdasarkan tabel tersebut, dapat dilihat bahwa sig (2-tailed) $=0,000$ dalam hal ini berarti bahwa $p$ value kurang dari $\alpha$ atau $(0,000<0,05)$. Sesuai dengan kriteria 
pengujian hipotesis $p$ value $<0,05$ maka $\mathrm{H}_{\mathrm{o}}$ ditolak dan $\mathrm{H}_{\mathrm{a}}$ diterima. artinya terdapat pengaruh model Numbered Head Together (NHT) terhadap hasil belajar siswa muatan PPKn Tema 8 Praja Muda Karana di kelas III SDN 30/II Tanjung. (Rismayani, 2019) bahwa salah satu Pembelajara menggunakan model Numbered Head Together (NHT) terbukti mampu meningkatkan hasil belajar siswa terutama pada pelajaran PPKn. Kontekstual merupakan model pembelajaran yang mengkaitkan materi pembelajaran dengan kehidupan sehari-sehari siswa, sehingga model Kontekstual tepat digunakan dalam pembelajaran PPKn. Serta dapat memberikan pengaruh yang baik terhadap hasil belajar PPKn siswa kelas III SDN 30/II Tanjung.

Langkah akhir pada penelitian ini adalah pemberian posttest. Posttest ini dilakukan setelah siswa diberi treatment (perlakuan). Soal posttest khusus pada muatan PPKn materi memahami arti gambar pada lambang negara garuda pancasila. Posttest ini dilakukan guna untuk mengetahui hasil belajar siswa setelah menggunakan model Numbered Head Together (NHT). Nilai posttest adalah nilai setelah siswa diberikan treatment (perlakuan) menggunakan model Numbered Head Together (NHT). Nilai posttest siswa kelas III SDN 30/II Tanjung.

Berdasarkan pemaparan hasil penelitian di atas dapat dibuktikan dengan data hasil penelitian yang menyatakan bahawa adanya peningkatan nilai rata-rata postest pada pembelajaran yang menggunakan model Numbered Head Together (NHT) lebih tinggi dibandingkan dengan pembelajaran yang tidak menggunakan model Numbered Head Together (NHT).

\section{KESIMPULAN}

Setelah dilakukan penelitian terhadap pengaruh model kooperatif tipe Numbered Head Together (NHT) terhadap hasil belajar PPKn pada siswa kelas III sekolah dasar, dan selanjutnya dilakukan pengolahan data yaitu uji normalitas dan uji paired samples $t$ test. Hasil uji paired samples $t$ test dengan taraf signifikansi $\alpha=0,05$. Berdasarkan tabel 4.3 dapat dilihat bahwa sig (2-tailed $)=0,000$ dalam hal ini berarti bahwa $p$ value kurang dari $\alpha$ atau $(0,000<0,05)$. Sesuai dengan kriteria pengujian hipotesis $p$ value $<0,05$ maka $\mathrm{H}_{\mathrm{o}}$ ditolak dan $\mathrm{H}_{\mathrm{a}}$ diterima sehingga dapat ditarik kesimpulan bahwa terdapat pengaruh model kooperatif tipe Numbered Head Together (NHT) terhadap hasil belajar PPKn tema 8 praja muda karana di kelas III SDN 30/II Tanjung. 


\section{DAFTAR PUSTAKA}

Diah, A., Kusmariyatni, \& Sumantri. (2017). Pengaruh Model Pembelajaran Kooperatif Tipe NHT Berbasis Kearifan Lokal Terhadap Hasil Belajar PKn Siswa. E-Journal Pgsd Universitas Pendidikan Ganesha, 5(2), 12.

Febriany, D. D., Siswandari, \& Ivada, E. (2013). Pengaruh Pembelajaran Kooperatif Tipe Numbered Heads Together (NHT) Untuk Meningkatkan Hasil Belajar Akuntansi Diny. Jupe Uns, 1(2), 1-11.

Kurniawan, Machful Indra. (2017). Meningkatkan Hasil Belajar Pendidikan Kewarganegaraan Melalui Strategi Active Learning. Pedagogia: Jurnal Pendidikan, 6(1), 124. Https://Doi.Org/10.21070/Pedagogia.V6i1.764

Pindo Hutauruk, Rinci Simbolon. (2018). Sej (School Education Journal) Vol. 8. No 2 Juni 2018. Upaya Meningkatkan Motivasi Belajar Siswa Dengan Menggunakan Metode Role Play Pada Pelajaran IPS Kelas IV SD Swasta Xaverius Padang Sidimpuan, 8(2), 112.

Prananda, G. (2019). Pengaruh Model Pembelajaran Kooferatif Tipe STAD Dalam Pembelajaran IPA Siswa Kelas v SD. 6(2).

Prananda, G. (2020). Meningkatkan Hasil Belajar Menggunakan Media Lagu Anak Dalam Pembelajaran IPA Sekolah Dasar. 8(2), 304-314.

Rismayani. (2019). Pengaruh Model Pembelajaran Numbered Head Together Berorientasi Tri Hita Karana Terhadap Hasil Belajar PKn. Jurnal Pendidikan IPS Indonesia, 3(1), 32-41. Https://Doi.Org/10.23887/Pips.V3i1.2879

Shoimin, A. (2014). Model Pembelajaran Inovatif. Ar-Ruzz Media.

Sugiyono. (2019). Metode Penelitian Kuantitatif, Kualitatif, Dan R\&D. Alfabeta.

Utami, P. (2018). Pengaruh Model NHT Terhadap Prestasi Belajar PKn Siswa The Effects Of NHT Model Towards Civics Achievement Of Fifth Grade. Pendidikan Guru Sekolah Dasar. 